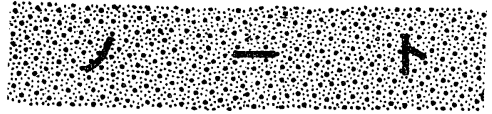

\title{
電子レンジ使用による合成樹脂製食器の変化
}

一一特に食器からのホルムアルデヒドの溶出—

(昭和 48 年 12 月 11 日受理)

$\begin{array}{lll}\text { 山中すみへ*1 } & \text { 佐藤ひろみ*2 } & \text { 塩平真理子*2 } \\ \text { 武藤美保子*2 } & \text { 西 村 正 雄*1 }\end{array}$

\section{Effects of Electric Range Cooking on Plastic Tableware}

-Especially on the Exudation of Formaldehyde from Tableware-

$$
\text { Sumie YamanaKa*1, Hiromi Sato*2, Mariko Shiohira*2, . }
$$
Mihoko MUTo*2 and Masao NishimURA*1

(*1Department of Hygiene, Tokyo Dental College; 2-9-18, Misaki-cho, Chiyoda-ku, Tokyo; *2Faculty of Home Science, Rissho Women's University; Detsu 3337, Minamiogishima, Koshigaya-shi, Saitama)

The change of the tableware made of synthetic resin by using of electric range cooking was studied. In this paper, the increase of formaldehyde exudation from tablewares was primarily investigate. Furthermore the surface appearance of tablewares were also observed with a reflecting microscope and a surface roughness meter. The following results were obtained:

1. The amount of exuded formaldehyde from tablewares was higher when it was used in an electric range cooking for 2 min, than when it was treated by the standard procedure of using water at $80^{\circ} \mathrm{C}$ or $4 \%$ acetic acid at $80^{\circ} \mathrm{C}$.

2. In case of phenol resin, formaldehyde exudation did not increased, though the surface change was observed with naked eyes.

3. In case of melamine resin, the average amount of formaldehyde exudation increased to $2.1 \mathrm{ppm}$ from $1.3 \mathrm{ppm}$.

4. In case of urea resin, the average amount of formaldehyde exudation increased to $7.1 \mathrm{ppm}$ from $2.5 \mathrm{ppm}$. It was over $4 \mathrm{ppm}$ fixed as the acceptable level.

5. From old tablewares which were used at home for long period exuded more formaldehyde by electric range cooking. In one case, as high as $71 \mathrm{ppm}$ was detected.

6. Formaldehyde exudation was correlated with the surface roughness of tablewares.

(Received December 11, 1973)

1.はじめに

合成樹脂製食器は軽くて割れない食器として, 一般家

*1 東京歯科大学衛生学教室：千代田区三崎町 2-9-18

*2 立正女子大学 家政学部：埼玉県越谷市南荻島出津 3337
庭では特に幼児用, 子供用として, また社員食堂や学生 食堂でも広く用いられている. しかし，ニリア樹脂やメ ラミン樹脂からのホルムアルデヒドの溶出という食品衛 生上の大きな問題点が提起されている11,2).

一方, 電子レンジも電磁波の漏出という問題点孔解決 
されて一般家庭にもかなり普及するようになった。電子 レンジ使用に当たっては合成樹脂製食器は「注意して使 用すべき食器」とは書かれているが，「一般には使用し てもよい」となっており，家庭ではみそ汁やその他の食 物を温め直すのによく使用されているものと思われる.

そこで今回，電子レンジ使用による合成樹脂製食器の 変化を表面アラサ計や光学反射顕微鏡などで観察し，そ れと同時に食器からのホルムアルデヒドの溶出について も検討したので報告する.

\section{2. 実験材料および実験方法}

\section{1 装}

置

電子レンジ：ナショナル製 $\mathrm{NE}-4800$ 型 表面アラサ計：小坂研究所製，SE-3 型

光学反射顕微鏡：オリンパス光学工業株式会社製金属 影微鏡 PMF

\section{2 試 料}

新しい食器：フェノール樹脂製10個，ユリア樹脂製12 個，メラミン樹脂製19個，(そのうち幼児用はユリア樹 脂製 1 個とメラミン樹脂製 8 個）を東京, 埼玉の小売店 やスーパーマーケットで買い求めた。

古い食器：一般家庭や大学食堂で長期間 ( 1 年 15年 間）使用した11個で，そのらちメラミン樹脂製と刻印さ れたものは 6 個で，他は材質が不明であった。

\section{3 試験溶液の調製}

通常の溶出試験では，食器に $80^{\circ}$ の水または $4 \%$ 酢酸 $100 \mathrm{ml}$ を加党, 30 分間, $80^{\circ}$ の恒温に保った後, 冷却後 試験溶液とした。 その他の溶出条件としては，4\%酢酸 で室温 30 分間放置した試験溶液や，水または $4 \%$ 眽酸 $100 \mathrm{ml}$ を食器に入れ 2 分間電子レンジに入れた後, $80^{\circ}$ の恒温に30分間保った試験溶液などを作製した。

また繰り返し試験では, その都度新しい溶出液を入れ て, 電子レンジで 2 分間繰り返し使用した。な㧤, 電子 レンジの 2 分間の使用で, 約 $80^{\circ}$ の水温となった。

\section{4 ホルムアルデヒドの定量}

衛生試験法 ${ }^{3)}$ に準じクロモトロプ酸法を採用し，標準 溶液はへキサミンを用いて作製した。

\section{5 食器表面の観察}

ホルムアルデヒド溶出試験後の試料を用いて, 溶出液 と接触していた部分を観察した。光学反射顕微鏡では試 料を $1 \mathrm{~cm}^{2}$ に切り，数視野観察して平均的な表面の状 態を 100 倍に拡大撮影し，また表面アラサ計では試料を 約 $0.25 \mathrm{~cm}^{2}$ に切って, 数か所の表面を走查し5000倍拡 大して表面のアラサを測定した。

\section{3. 実験結果および考察}

\section{1 種々の条件でのホルムアルデヒドの溶出}

新しいユリア樹脂, メラミン樹脂製食器について溶出 条件を変えてホルムアルデヒド溶出量の違いを調べた結 果が Table 1 である. 4 \%酶酸で室温の条件ではほと んどホルムアルデヒドが溶出しないが， $80^{\circ}$ の温水では 基準偡の $4 \mathrm{ppm}$ を越光るホルムアルデヒドを溶出する ものがユリア樹脂の中にあった。 また $80^{\circ}$ の 4 \%酶酸で は $80^{\circ}$ の温水よりも多くのホルムアルデヒドを溶出した が，酸性溶液の方がホルムアルデヒドの低分子化合物の 分解性や溶解性が増すためと考兄られる．さらに電子レ ンジを使用すると温水の $2 \sim 9$ 倍のホルムアルデヒドが 溶出し, ユリア樹脂のすべてが $4 \mathrm{ppm}$ を越光，メラミ ン樹脂の中にも $29 \mathrm{ppm}$ と非常に高いものがあった。こ れは電子レンジの使用により食器の表面に変化が 起こ り，ホルムアルデヒドが溶出しやすくなったものと考兄 られる.

\section{2 溶出時間による ホルムアルデヒド溶出量の変化}

電子レンジの使用によりホルムアルデヒド溶出量が明 らかに增加したが，さらにその変化を $80^{\circ}$ 恒温空中の保 存時間を变えて調べた。

すなわち水を加光て電子レンジで 2 分間使用後, $80^{\circ}$ 恒温室に入れ，直後， $10 ， 30,60$, 拈よび 120 分後に試 験溶液をとり，ホルムアルデヒド溶出量の増加を調べた 結果が Fig. 1 である. 電子レンジから出した直後には ほとんぞホルムアルデヒドは溶出しないが，10分後には かなりの溶出があり，その後徐々に増加する傾向がみら れた。このことから電子レンジの電磁波により食器の表 面に変化が生じ，その後水溶液と接してホルムアルデヒ

Table 1. The Amount of Formaldehyde in Various Exuding Conditions

\begin{tabular}{c|c|c|c|c} 
& \multicolumn{3}{|c}{ The amount of exuded formaldehyde (ppm) } \\
\hline $\begin{array}{c}\text { Sample } \\
\text { No. }\end{array}$ & $\begin{array}{c}4 \% \mathrm{CH}_{3} \mathrm{COOH} \\
\text { Room temp., } 30 \mathrm{~min}\end{array}$ & $\begin{array}{c}80^{\circ} \mathrm{C} \mathrm{H}_{2} \mathrm{O} \\
80^{\circ} \mathrm{C}, 30 \mathrm{~min}\end{array}$ & $\begin{array}{c}4 \% \mathrm{CH}_{3} \mathrm{COOH} \\
80^{\circ} \mathrm{C}, 30 \mathrm{~min}\end{array}$ & $\begin{array}{c}\text { Electric range 2 min } \\
\mathrm{H}_{2} \mathrm{O}, 80^{\circ} \mathrm{C}, 30 \mathrm{~min}\end{array}$ \\
\hline U. 10 & N.D. & 1.7 & 4.0 & 15.3 \\
11 & N.D. & 5.1 & 11.3 & 37.4 \\
12 & N.D. & 1.9 & 4.0 & 9.5 \\
\hline M. 14 & N.D. & 1.3 & 1.0 & 2.2 \\
15 & 0.4 & 3.9 & 7.7 & 29.5 \\
16 & N.D. & 0.8 & 1.4 & 2.9
\end{tabular}

U., urea resin; M., melamine resin. 
Table 2. The Change of Plastic Tableware by Electric Range Cooking

The amount of exuded formaldehyde (ppm)

\begin{tabular}{|c|c|c|c|c|c|c|c|}
\hline \multirow{3}{*}{$\begin{array}{l}\text { Sample } \\
\text { No. }\end{array}$} & \multicolumn{5}{|c|}{ Electric range $2 \mathrm{~min}$} & \multirow{3}{*}{$\mathrm{H}_{2} \mathrm{O}, 80^{\circ} \mathrm{C}, 30 \mathrm{~min}$} & \multirow{3}{*}{$\begin{array}{c}4 \% \mathrm{CH}_{3} \mathrm{COOH} \\
80^{\circ} \mathrm{C}, 30 \mathrm{~min}\end{array}$} \\
\hline & \multicolumn{4}{|c|}{$\mathrm{H}_{2} \mathrm{O}, 80^{\circ} \mathrm{C}, 30 \mathrm{~min}$} & \multirow{2}{*}{$\begin{array}{c}4 \% \mathrm{CH}_{3} \mathrm{COOH} \\
80^{\circ} \mathrm{C}, 30 \mathrm{~min}\end{array}$} & & \\
\hline & 4 th & 5 th & 6 th & Ave. & & & \\
\hline P. 1 & 0.9 & 0.6 & 0.5 & 0.7 & 1.1 & 1.2 & 0.6 \\
\hline 2 & 0.9 & 0.6 & 0.3 & 0.6 & 0.6 & 0.4 & 0.6 \\
\hline 3 & 1.0 & 0.4 & 0.5 & 0.6 & 0.8 & 0.5 & 0.6 \\
\hline 4 & 0.6 & $0.1^{*}$ & 0.5 & 0.4 & 0.1 & 0.3 & 0.2 \\
\hline 5 & 0.6 & 0.7 & 0.3 & 0.5 & 1.3 & 0.6 & 0.9 \\
\hline 6 & 0.6 & 0.7 & 0.3 & 0.5 & 1.9 & 0.6 & 0.9 \\
\hline 7 & 0.6 & $0.3^{*}$ & 0.4 & 0.4 & 2.1 & 0.2 & N.D. \\
\hline 8 & 0.2 & $0.4^{*}$ & 0.3 & 0.3 & 1.5 & 0.4 & 0.1 \\
\hline 9 & 1.3 & 0.5 & $0.3^{*}$ & 0.6 & 1.7 & 0.4 & 0.8 \\
\hline 10 & 1.0 & 0.6 & $0.5^{*}$ & 0.6 & 1.4 & 0.6 & 0.4 \\
\hline Ave. & 0.8 & 0.5 & 0.4 & 0.5 & 1.2 & 0.5 & 0.5 \\
\hline M. 1 & 4.3 & 2.7 & $3.0 *$ & 3.3 & 10.8 & 1.1 & 2.8 \\
\hline 2 & 3.3 & 3.0 & 2.9 & 3.1 & 8.5 & 1.2 & 3.6 \\
\hline 3 & 0.5 & N.D. & 2.4 & 1.0 & 0.4 & 0.4 & 0.9 \\
\hline 4 & 1.8 & 0.6 & 2.4 & 1.6 & 0.8 & 0.5 & 0.2 \\
\hline 5 & 0.8 & 0.5 & 2.5 & 1.3 & 1.4 & 0.6 & 0.4 \\
\hline 6 & 2.5 & $1.4^{*}$ & 1.6 & 1.8 & 1.7 & 1.3 & 1.5 \\
\hline 7 & 1.8 & 1.2 & 1.1 & 1.3 & 0.3 & 0.9 & 1.3 \\
\hline 0 & 1.9 & 0.7 & 0.7 & 1.1 & 0.9 & 0.6 & 0.4 \\
\hline - 9 & 2.6 & 1.7 & 1.3 & 1.9 & 4.2 & 1.5 & 2.7 \\
\hline - 10 & 0.9 & 1.6 & 1.1 & 1.4 & 1.3 & 1.1 & 0.7 \\
\hline - 11 & 3.9 & 1.6 & 9.2 & 4.9 & 12.3 & 3.2 & 5.3 \\
\hline - 12 & 2.5 & 2.0 & 3.7 & 2.7 & 7.0 & 2.3 & 2.1 \\
\hline - 13 & 1.2 & 4.2 & 2.9 & 2.7 & 6.0 & 1.4 & 2.0 \\
\hline Ave. & 2.1 & 1.6 & 2.6 & 2.1 & 11.3 & 1.3 & 1.8 \\
\hline U. 1 & 12.0 & 12.5 & 4.8 & 8.6 & 22.0 & 3.7 & 5.7 \\
\hline 2 & 19.5 & $17.5^{*}$ & 15.5 & 16.5 & 17.3 & 4.2 & 12.3 \\
\hline 3 & 0.6 & $0.8^{*}$ & 1.5 & 1.1 & 0.7 & 0.9 & 0.3 \\
\hline 4 & 6.8 & $3.4^{*}$ & 9.3 & 6.3 & 10.7 & 2.6 & 4.8 \\
\hline 5 & 6.9 & $4.0^{*}$ & 7.4 & 6.1 & 12.5 & 3.2 & 4.0 \\
\hline 6 & 0.9 & $1.1^{*}$ & 1.6 & 1.2 & 1.3 & 0.3 & 0.4 \\
\hline 7 & 0.9 & $1.1^{*}$ & 1.2 & 1.0 & 2.3 & 0.8 & 0.6 \\
\hline 8 & 1.2 & 0.9 & 1.0 & 1.3 & 1.2 & 0.5 & 0.4 \\
\hline - 9 & 37.5 & 12.8 & 15.0 & 21.7 & 36.3 & 6.3 & 34.8 \\
\hline Ave. & 9.6 & 6.0 & 6.4 & 7.1 & 11.6 & 2.5 & 7.0 \\
\hline
\end{tabular}

P., phenol resin; M., melamine resin; U., urea resin.

* The surface change was observed with naked eyes.

, tableware for infant. 


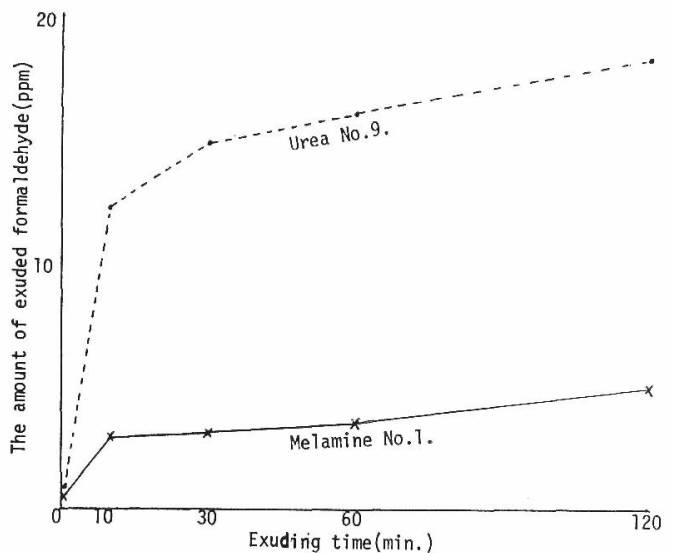

Fig. 1. The change of the amount of formaldehyde by various exuding periods after electric range cooking (for $2 \mathrm{~min}$, exuded by $80^{\circ} \mathrm{C} \mathrm{H}_{2} \mathrm{O}$ )

ドが溶出してくるものと考えられる.

\section{3 電子レンジの繰り返し使用による变化}

次に電子レンジを数回繰り返し使用した場合の変化を フェノール樹脂，メラミン樹脂，ユリア樹脂について調 ベた結果を Table 2 に示した。新しい食器を電子レン ジに使用したのであるが，早くも5回目の繰り返し使用 で肉眼的な变化（亀裂や山凸）や変色の及られるものが あった．特に熱に弱いユリア樹脂に多かったが，フェ， 一ル樹脂やメラミン樹脂の中にもあり, 幼览用食器で煮 沸可と表示されている8, (M. 6) 飞与変化が生じてい
た。一方, 溶出ホルムアルデヒド量をみると，フェノー ル樹脂では個々のばらつき斥少なく平均値も $0.5 \mathrm{ppm}$ と低くて，電子レンジ繰り返し使用の影響は2られなか った. ィラミン樹脂やュリア樹脂ではその影響がみら れ，特にュリア樹脂では最高 $37.5 \mathrm{ppm}$ (U. 9) のもの があり，平均值で $7.1 \mathrm{ppm}$ と基準值をはるかに越えて いた．水で電子レンジ 6 回使用後，4\%酢酸を溶出液と して電子レンジを使用するとやはり水の場合よりも約 2 倍高いホルムアルデヒドの溶出がみられた。その後さら に通常の溶出条件，すなわち $80^{\circ}$ 温水で 30 分間溶出した が，電子レンジ使用の影響は残って㧍らず約 $1 / 2 \sim 1 / 3$ の 溶出ホルムアルデヒド量に減少していた。

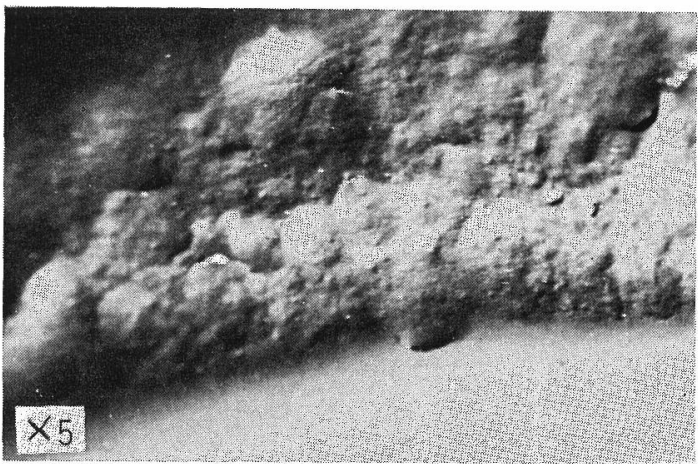

Fig. 2. Surface condition of phenol resin No. 7. This change was observed with naked eyes $\mathrm{HCHO}: 0.4 \mathrm{ppm}$

Table 3. The Amount of Formaldehyde Exuded from Old Tablewares which were Used at Home for Long Period

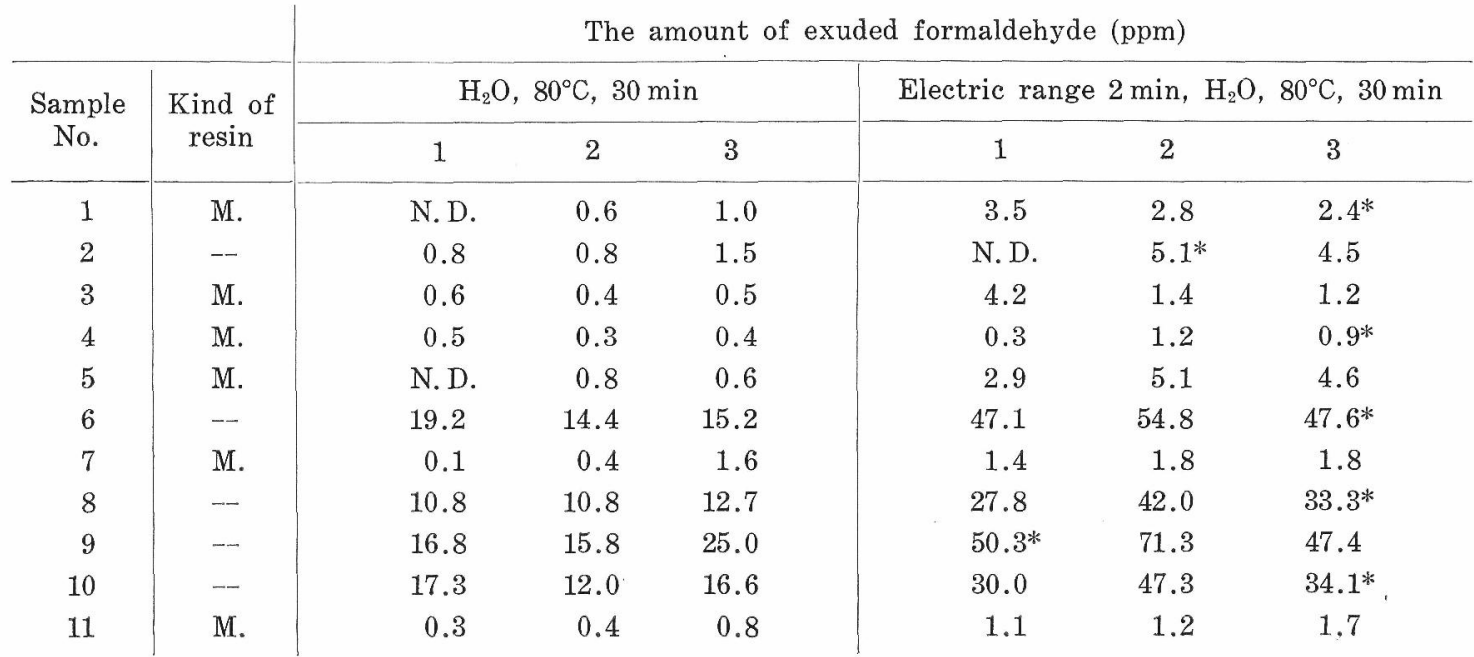

M., melamine resin; --, the kind of resin was unknown.

* The surface change was observed with naked eyes. 


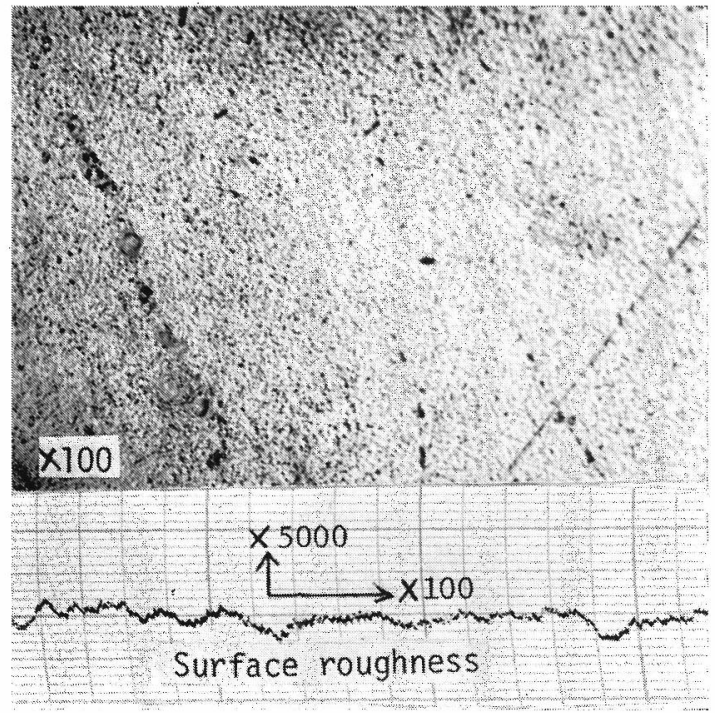

Fig. 3. Surface condition of melamine resin No. 17 before electric range cooking $\mathrm{HCHO}$ : not detected
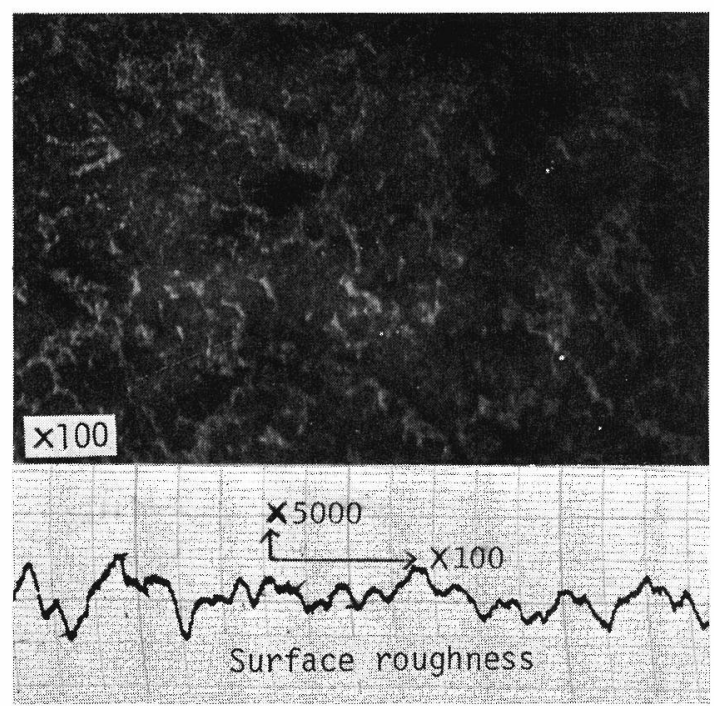

Fig. 5. Surface condition of urea resin No. 9 for infant HCHO : $21 \mathrm{ppm}$

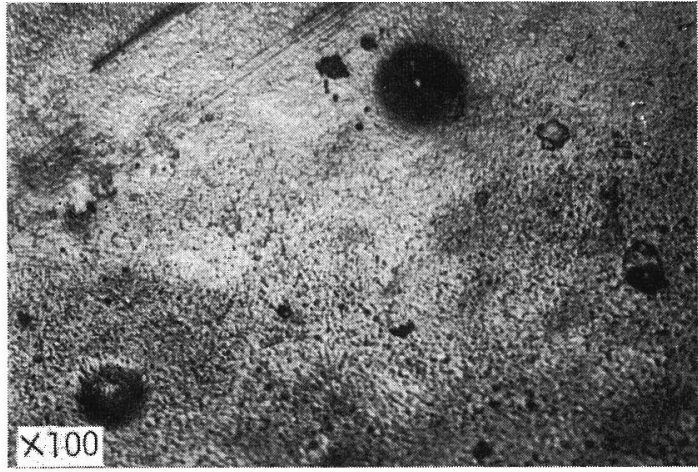

Fig. 4. Surface condition of melamine resin No. 10 after electric range cooking 19 times $\mathrm{HCHO}: 0.3 \mathrm{ppm}$
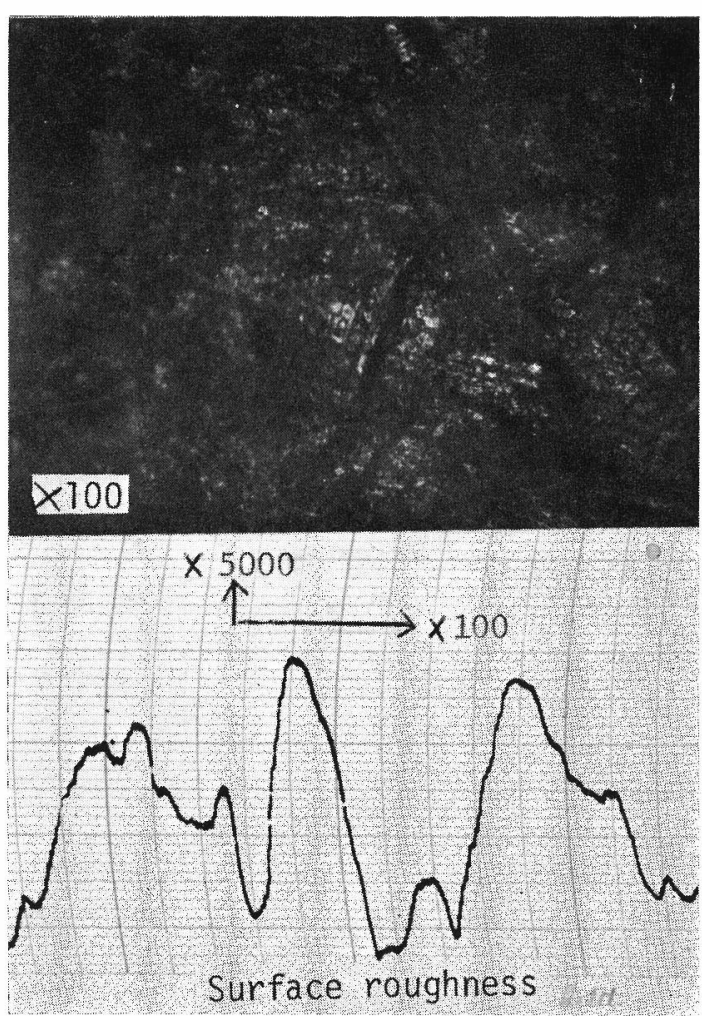

Fig. 6. Surface condition of the old tableware No. 9 which was used at home for 10 years HCHO : $71 \mathrm{ppm}$

Fig. 3 6. The surface appearance observed with a reflecting microscope and a surface roughness meter 


\section{4 古い食器の電子レンジ使用による变化}

一般家庭や大学食堂で長時間使用した食器について電 子レンジ使用による変化や溶出ホルムアルデヒド量を調 ベた結果が Table 3 である.

これらはいずれも今まで電子レンジで使用されたこと がなかったが長期間の使用により軽いひびがあり，早く も電子レンジ 1 回の使用で亀裂などが生じるものがあっ た. たた溶出ホルムアルデヒド量は, メラミン樹脂と刘 印されているものは新しい食器との差がなく低かった が，無刻印のもの (No.6，8，9，10) ではかなり高く, 通常の温水による溶出条件でも最高 $25 \mathrm{ppm}$ ののもあ り,さらに電子レンジ使用の場合には最高 $71 \mathrm{ppm}$ と非 常に高い溶出ホルムアルデヒド量であった。 これらは昔 売られていたユリア樹脂製のもので長期間の使用により 軽いキズができ，さらに電子レンジ使用により表面が変 化してホルムアルデヒドが溶出しやすくなったものと推 察される.

\section{5 食器の表面変化の観察}

ホルムアルデヒドの溶出は食器表面の変化に伴って生 じるものと考えて，光学反射顕微鏡や表面アラサ計によ って表面の観察を行った. 肉眼でも観察でさる凹凸が 生じた例 (Table 2, P. 7) を Fig. 2 に示したが，この よらな変化は Table 2, 3 にみられるように多くの食器 に観察された。 しかしこれらの変化は溶出液の境界面の 上部に生じており，溶出液には直接接することがないの で, これらの肉眼的変化のためにホルムアルデヒドの溶 出量が急増することはなかったと考えられる. 次に溶出 液に浸された部分について肉腿では観察でさない変化を 示したのが Fig. 3〜6 である. Fig. 3, 4 は同時に製造 されたメラミン樹脂製であるが，Fig. 3 は電子レンジ 使用前のもので表面は $0.8 \mathrm{~nm}$ 以下の凹凸で変化もみら れなかった，Fig. 4 は電子レンジ10回使用後で，凹凸 はFig. 3 と変らず $0.8 \mathrm{~nm}$ で, 反射顕微鏡でも微細変 化が観察されただけであり, 溶出ホルムアルデヒド量が $0.3 \mathrm{ppm}$ と少なかったこととも一致しており比較的変化 の少ない試料といえる. 次にホルムアルデヒド溶出量の 多い食器 (Table 2, U. 9) の表面が Fig. 5 であるが, 凹凸も $2 \mathrm{~nm}$ と大きく表面の分解も写真から明らかであ る.ささらに古い食器で溶出ホルムアルデヒド量が 71 ppm と高い例 (Table 3, No. 9) が Fig. 6 であるが, 長期間の使用と電子レンジ使用によりキズや変化が生じ
凹凸も $6.6 \mathrm{~nm}$ と大きい。なお古い食器でもホルムア ルデヒド溶出量の少ない試料では凹凸も $1 \mathrm{~nm}$ 以下で， 顕微鏡によっても大きな変化は観察されなかった.

以上の結果よりホルムアルデヒド溶出量と表面の凹凸 や変化と相関していることは明らかであり, 電子レンジ の使用により肉眼的に観察できる変化はもちろん, 肉眼 で観察できない微細な分解が生じ, その結果溶出ホルム アルデヒド量が増加すると考えられる。

\section{4. 総 括}

昭和41年，主婦連がュリア樹脂製食器の有毒説を発表 して以来, ユリア樹脂やメラミン樹脂製食器からのホル ムアルデヒドの溶出について多くの報告 ${ }^{1)}{ }^{2)}$ があるが， 本報告は特に最近普及しつつある電子レンジを使用した 場合の結果である.フェノール樹脂は肉眼的な変化が生 じるにもかかわらずホルムアルデヒド溶出量は少なく,

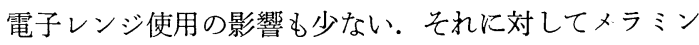
樹脂やユリア樹脂では電子レンジ使用の影響がみられ， 特にユリア樹脂では平均值 $7.1 \mathrm{ppm}$ と基準值をはるか に越えていた，さらに古い食器では早くも 1 回目の電子 レンジ使用で亀裂などが生じ溶出ホルムアルデヒド量も 最高 $71 \mathrm{ppm}$ と高かった。 また食器表面の変化では溶 出液に浸されない部分に生じる肉眼的な変化以外に，溶 出液に浸される部分に微細な分解が生じることが認めら れた。このような変化は溶出ホルムアルデヒド量と相関 がタられた。

以上の結果からメラミン樹脂, ユリア樹脂製食器は電 子レンジに使用すべきでないといえる. 特に電子レンジ の影響を受けやすいュリア樹脂については, メーカー側 の自主的な規制で製造されなくなったとはいえまだ店頭 に並んでいることがあり，また古くから使われているこ とがあるので注意が必要である. しかし多くの食器は材 質を刻印せずにラベルを張っているだけで材質が分から なくなりやすいので, むしろ現状ではすべての合成樹脂 製食器の電子レンジ使用は好ましくないと指導すべきで ある。

文献

1) 高崎宗利：食品と科学，9，50 (1972).

2) 和田 裕, 渡辺重信, 高橋武夫：食衛誌. 14, 219 (1973).

3) 日本薬学会編：“衛生試験法注解” p. 504. 